\title{
IMPROVING STUDENTS' ABILITY IN WRITING DESCRIPTIVE TEXT BY USING REALIA MEDIA
}

\author{
Aris M. Girsang, Nitha F. V Liando, Mister G. Maru
}

\begin{abstract}
The aim of this research was to investigate whether the use of realia is effective in improving tenth grades ability in writing descriptive text or not. The research conducted at SMA Negeri 1 Tompaso, North Sulawesi, Indonesia, in which X MIPA 1 was chosen as the sample. This class consists of twenty-nine students. This quantitative research used a pre-experimental design with one group pre-test and post-test design. Pre-test has given before the treatment. After the writer gave a treatment, the writer collected the data for post-test. The result of this research showed that the mean score of pre-test is 4.86 and post-test is 7.48. This means that the result of post-test is higher than pre-test. In other words, this result may lead to conclusion that using realia media was considered to improve students' ability writing descriptive.
\end{abstract}

\section{Keywords: Realia Media, Writing, Descriptive Text}

\section{INTRODUCTION}

Nowadays many people include Indonesian learn English because English is an International language. In learning English as foreign language helped us to communicate with others using English (Maru, 2009). In other words, many people have to mastering English including Indonesian because English is very important. In Indonesia, students learn English as a foreign language. There are four skills should be mastered by students. They are listening, speaking, reading and writing. Among the four main language skills, the writer focuses on writing skill.

Since in junior high school, students learn many kinds of genre text as material to study English, one of them is descriptive text. In descriptive text, the students are asked to explain/describe about something or someone. The information is written by considering with several aspects such as grammar, punctuation, and structure of the text so the students can create a descriptive text well. It means that student should master this skill because they already learnt about it in junior high school. 
In fact, based on writer's observation, the students have some problems in writing descriptive text. The first problem is some students cannot get idea because they have to describe something that they have never seen directly before by using their imagination. Beside it, their idea and sentences are not well organized. Another problem in writing is students are lack of vocabularies, and have low motivation during teaching learning process. Based on the statement above, the writer tried to solve students' problem in writing by using realia (real life things) as the media to teach the students how to write descriptive text.

Reason to choose this topic because writing as one of important skill should be mastered by students using good media. Realia as media help students easier to understand the material and enjoyable along teaching learning process in the class.

Thus, the purpose of this study is to investigate whether the use of realia can be effective in improving tenth grades ability in writing descriptive text or not. This study is further to be significant for students to learn to describe someone or something based on what he or she sees directly, for teachers to apply real objects as a reference to guide them to improve their ability in teaching writing, and for school to be an alternative method to improve the teaching and learning process. This research delimited to explain the use of realia of mobile phone based on the specifications, age, color, function, and country that produce that mobile phone. This study used product approach and focus to grammar and mechanic to measure students writing skills.

\section{RESEARCH METHODS}

This research used quantitative research through pre-experimental design with one group pre-test and post-test design. $T_{1}$ is the pre-test and $T_{2}$ is the posttest. X used to symbolize the treatment in the following representation of the design:

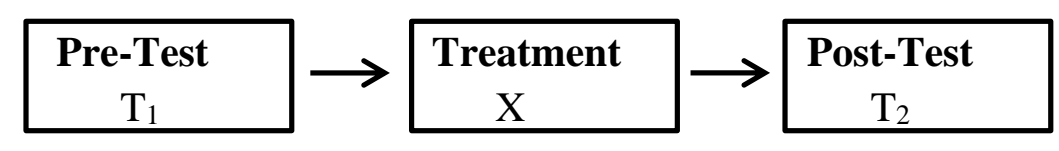

\section{Subject of Study}

The subject of this research was tenth grades students at SMA Negeri 1 Tompaso, in class X MIPA 1 that consist of 29 students.

\section{Data Collection}

The data were collect by using test. The kind of test was subjective test of essay to evaluate students' achievement in writing descriptive text. Adapted from Cohen (1996), this research focused on students' grammar and mechanic 
(punctuation and spelling). In this research, the maximum' score of students' writing is ten and minimum score is two.

In analyzing the data, the writer used the mean score formula.

$$
\overline{\mathrm{X}}=\frac{\Sigma x}{\mathrm{~N}}
$$

(Moore, 1983:37)

Standard deviation calculated by using raw score method:

$$
\mathrm{S}=\sqrt{\frac{\sum(\mathrm{X}-\overline{\mathrm{X}})^{2}}{\mathrm{~N}-1}}
$$

\section{DATA ANALYSIS}

(Moore, 1983:251)

\section{Research Findings}

After finishing the process of pre-test, treatment, and post-test, the writer calculated the differences between mean and standard deviation of pre-test and post-test. The writer did some procedures to show that this study was consistent to investigate whether the use of realia was effective in improving tenth grades ability in writing descriptive text or not. The sample of this research consists of twentynine students at X MIPA 1 of SMA Negeri 1 Tompaso. The writer taught descriptive text in the class using realia. The process explained as following.

In the first meeting, the writer asked the students to rearrange a text from random sentences to good sentences. In the draft, the writer made it irregular mechanics (punctuation and spelling) and grammar error. This T1 (Pre-test), administered to show that the most score that gotten by nine (9) students were four (4) or $31.0 \%$. The mean score of this test is 4.86 with the standard deviation of pretest is 1.25 .

After pre-test in the first meeting, the writer applied speech method where this method is favourite method that used by teacher to present the material. The writer presented the material of descriptive text about tourism place based on their book (Bahasa Inggris Kelas X Edisi Revisi 2016) and modul that is given by teacher before teaching learning process. In addition, the writer used this method to investigate students' respons before applying realia. The students' got bored because they received new material with the same method. Beside it, this method centered to teacher. It made teacher do not know how far students' comprehended the material. It also indicated the students' achievements still low. The writer used realia to increase students' motivation in learning English. In addition, students need motivation to expended attention when they learning in foreign language (Liando: 2012 p.268).

The second meeting, the writer applied realia as media when teaching descriptive text. During teaching learning process, the writer presented the material using mobile phone as realia media. After that, the writer asked the students to write about their own mobile phone. As stated in chapter I, the students should include 
some information when they explained the use of realia of their phone based on the specifications, age, color, function, and country that produce the mobile phone. For example, when a student wants to describe about his phone, then he should have background knowledge about classifications of his phone. In addition, during teaching learning process the writer observed students' activity. It was done to find out if realia can influence the students' motivation. Using realia help the students easily to understand the material and make them enjoyable along teaching learning process in the class.

In the end of meeting, the writer made a test to measure the students' ability in writing descriptive text. This test is called T2 (post-test). To analyse this test, the writer focused on students' grammar and punctuation. The result showed that the students' mean score is 7.48 and the standard deviation is 1.06. To describe the data clearly, the writer used SPSS 20 where the data putted on the table. The data obtained from T1 (Pre-test) to T2 (Post-test) is show in Table 1.

Table 1: The scores of students in pre-test (T1) and post-test (T2).

\begin{tabular}{|c|c|c|}
\hline Code Name & Pre-test (T1) & Post-test (T2) \\
\hline S-1 & 7 & 9 \\
\hline S-2 & 5 & 8 \\
\hline S-3 & 6 & 8 \\
\hline S-4 & 4 & 7 \\
\hline S-5 & 5 & 7 \\
\hline S-6 & 5 & 8 \\
\hline S-7 & 4 & 7 \\
\hline S-8 & 6 & 8 \\
\hline S-9 & 4 & 7 \\
\hline S-10 & 6 & 9 \\
\hline S-11 & 4 & 6 \\
\hline S-12 & 6 & 9 \\
\hline S-13 & 7 & 9 \\
\hline S-14 & 4 & 6 \\
\hline S-15 & 4 & 7 \\
\hline S-16 & 5 & 8 \\
\hline S-17 & 6 & 9 \\
\hline S-18 & 6 & 9 \\
\hline S-19 & 7 & 8 \\
\hline S-20 & 4 & 8 \\
\hline S-21 & 3 & 6 \\
\hline S-22 & 5 & 6 \\
\hline & & 6 \\
\hline
\end{tabular}

JELLT (Journal of English Language and Literature Teaching) 


\begin{tabular}{|l|l|l|}
\hline S-23 & 4 & 6 \\
\hline S-24 & 3 & 6 \\
\hline S-25 & 5 & 7 \\
\hline S-26 & 3 & 6 \\
\hline S-27 & 4 & 7 \\
\hline S-28 & 3 & 7 \\
\hline S-29 & 6 & 8 \\
\hline
\end{tabular}

The data presented on table 1, shows that in T1 (Pre-test) three (3) students got highest score of seven (7) and four (4) students got lowest score of three (3). On the other hand, in the T2 (Post-test), six (6) students got the highest score of nine (9) and the lowest score of six (6) by six (6) students. The result of score post-test was higher than pre-test where the mean in pre-test is 4.86 and in post-test 7.48 . It means students' ability in writing descriptive text by using realia media is effective.

Table 2: Frequency distribution of pre-test (T1)

\begin{tabular}{|c|c|c|c|}
\hline SCORES & TALLY & FREQUENCY & $\boldsymbol{\%}$ \\
\hline 7 & III & 3 & 10.3 \\
\hline 6 & III II & 7 & 24.1 \\
\hline 5 & III I & 6 & 20.7 \\
\hline 4 & III IIII & 9 & 31.0 \\
\hline 3 & IIII & 4 & 13.8 \\
\hline
\end{tabular}

The data presented in the table above shows that were 29 students took in T1 (Pre-test). The highest grade was seven (7) achieved by three (3) students (or $10.3 \%$ ), seven (7) students who got six (6) (or 24.1\%), six (6) students got five (5) (or 20.7\%), nine (9) students got four (4) (or 31.0\%) and four (4) students who got three (3) (or 13.8\%). The frequency distribution of scores T1 (pre-test) presented in the Figure 1. 


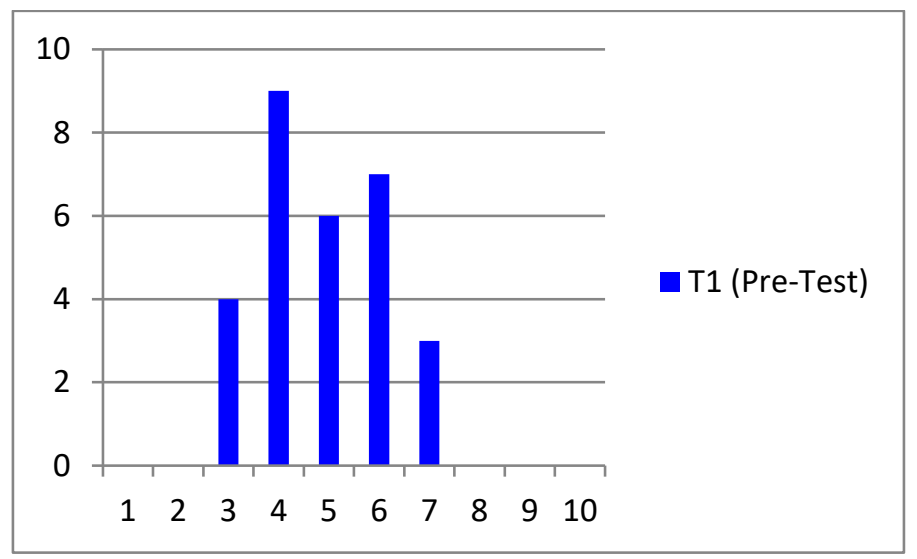

Figure 1. Chart Bar of T1 (Pre-test)

After calculating the frequency matrix of pre-test, the writer computed the mean and standard deviation of pre-test. Thus, mean score and standard deviation are:

$$
\begin{array}{rlrl}
\Sigma \mathrm{X} & =141 & \mathrm{~S} & =\sqrt{\frac{\sum(\mathrm{X}-\overline{\mathrm{X}})^{2}}{\mathrm{~N}-1}} \\
\mathrm{~N} & =29 & & =\sqrt{\frac{43.46}{29-1}}=\sqrt{\frac{43.46}{28}} \\
\bar{x} & =\frac{\Sigma \mathrm{X}}{\mathrm{N}}=\frac{141}{29} & & =\sqrt{1.5521} \\
& =\mathbf{4 . 8 6} & & =1.2458=1.25
\end{array}
$$

Based on computed the mean and standard deviation of pre-test, show that the mean score of pre-test is 4.86 and the standard deviation is 1.25. After analysed the score of pre-test then the writer calculated the frequency distribution matrix of T2 (Post-test) that presented in table 3.

Table 3: Frequency distribution matrix of post-test (T2)

\begin{tabular}{|l|l|l|l|}
\hline Scores & \multicolumn{1}{|c|}{ Tally } & Freq & Freq-\% \\
\hline 9 & II I & 6 & 20.7 \\
\hline 8 & HI III & 8 & 27.6 \\
\hline 7 & HI IIII & 9 & 31.0 \\
\hline 6 & H世 I & 6 & 20.7 \\
\hline
\end{tabular}

The result of T2 (Post-test) presented in the table 3, shows that were 29 students took in T2 (Post-test). The highest grade was nine (9) achieved by six (6) students (or 20.7\%), eight (8) students who got eight (8) (or 27.6\%), nine (9) students got seven (7) (or 31.0\%), and six (6) students who got six (6) (or 20.7\%). The frequency distribution of scores of T2 (post-test) presented in figure 2. 


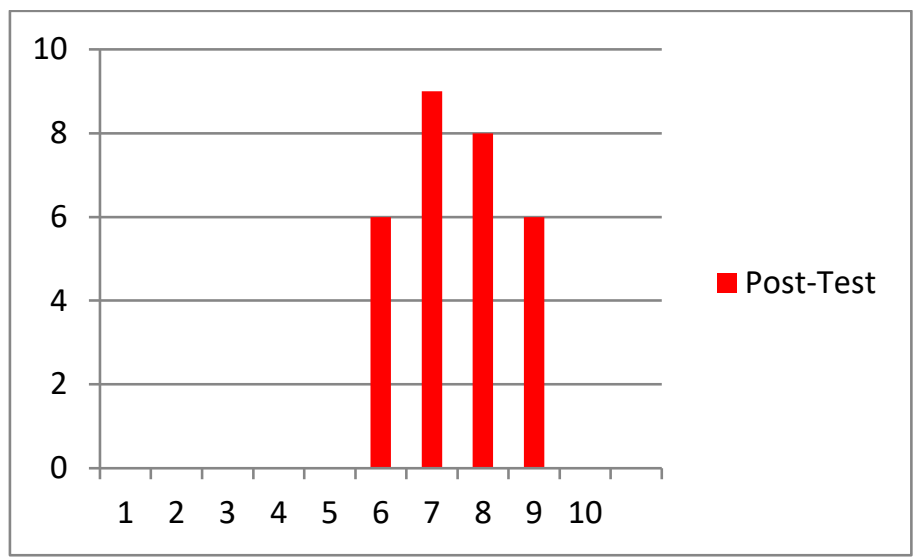

Figure 2. Chart Bar of T2 (Post-test)

After calculating the frequency matrix of pre-test, the writer computed the mean and standard deviation of pre-test. Thus, mean score and standard deviation are:

$$
\begin{array}{rlrl}
\Sigma \mathrm{X} & =213 & \mathrm{~S} & =\sqrt{\frac{\sum(\mathrm{X}-\overline{\mathrm{X}})^{2}}{\mathrm{~N}-1}} \\
\mathrm{~N} & =29 & & =\sqrt{\frac{\mathbf{3 1 . 2 4}}{28}}=\sqrt{1.1157} \\
\bar{x} & =\frac{\Sigma \mathrm{X}}{\mathrm{N}}=\frac{217}{29}=\mathbf{7 . 4 8} & & =\mathbf{1 . 5 0 6 2}=\mathbf{1 . 0 6}
\end{array}
$$

Based on the data above writer was summarised the result of pre-test and post-test to compare the result of this research clearly. The data putted in the Table 4.

Table 4. Recapitulation of result T1 (Pre-test) and T2 (Post-test)

\begin{tabular}{|l|c|c|}
\hline SCORE OF & Pre-Test & Post-Test \\
\hline Mean & 4.86 & 7.48 \\
\hline Mode & 4 & 7 \\
\hline Std. Deviation & 1.25 & 1.06 \\
\hline Minimum & 3 & 6 \\
\hline Maximum & 7 & 9 \\
\hline Sum & 141 & 217 \\
\hline
\end{tabular}

Based on the table above it showed that in T1 (pre-test) the mean score is 4.86 with the most score that gotten by nine (9) students was four (4). The standard deviation of pre-test is 1.25 with score minimum was three (3) got by four (4) students and the score maximum was seven (7) by three (3) students. Meanwhile, in T2 (post-test) the mean score is 7.48. The most score was seven (7) achieved by nine (9). The standard deviation of post-test is 1.06 with the minimum score is six 
(6) got by six (6) students, and maximum score is nine (9) by six (6) students. The sum of pre-test is 141 and post-test 217.

\section{DISCUSSION}

After implementing the use of realia in teaching descriptive text, the writer got the data of pre-test and post-test. The result showed than the score of pre-test was lower than post-test. In other words, realia as media was effective in improving tenth grades students' ability in writing descriptive text.

The result of pre-test that gotten by the writer showed the mean score of this test is 4.86 or it categorized as poor. The score showed that mostly students got four (4) or $31 \%$. Meanwhile, $34.4 \%$ or ten (10) students was achieved score above six (6). When analysed this score of pre-test the writer found the students' problem in grammar because of their vocabulary is low. Beside it, some of them did not know to put the right places of punctuation in their writing. It indicated their ability in writing still low especially when they wrote about descriptive text, their sentences are not clear. As stated by Maru (2016), “...essay writing demands cohesive ways in sense of the grammatical construction, the choice of the word and the punctuation use as well as the potential of analytical ability". It means that when the students express their ideas or argument in the paper, the must use good grammar, vocabulary and correct mechanics (punctuation and spelling).

During language teaching, the writer presented the material with realia (the actual object) that brought into a classroom as aids to be talked or written about and used in teaching. The result surprised the writer because students' more enthusiast in learning process. Beside it, the students' more critically to describe some object in front of them. It created the teaching learning process more enjoyable and active. In addition, students' ability in writing descriptive improved when they describe something that they can see directly.

In made sure the students' ability in writing descriptive the writer giving them a test to got score of post-test. The result showed that the students' ability in writing was improved. The score in this test is 7.48 and the standard deviation is 1.06. In this test the most score that achieved by students were seven (7).

In pre-test students' score low because the students cannot express their idea because they study English monotonously using speech method in teaching learning process. So the students need media to make the learning English more enjoyable and memorable (Rusman, 2005). The teacher is always used the same method when teaching English. Beside it, the teacher was seldom to sharpen students' ability in writing. That is why some students' punctuation are incorrect when writing descriptive text. When the writer asked them about this problem the students, they said that realia helped them in learning English more enjoyable and memorable.

\section{CONCLUSIONS}

JELLT (Journal of English Language and Literature Teaching)

Vol. 5 No.01 June 2020

P.ISSN: 2548-7728 E.ISSN: 2599-0373 
Before using realia as media to the tenth grades students of SMA Negeri 1 Tompaso, the result of students' ability in writing descriptive text in T1 (Pre-test) was 4.86 with standard deviation 1.25 . On the other hand, after using realia media in teaching writing descriptive text, the result T2 (Post-test) was 7.48 and the standard deviation 1.05. It means the score of T2 (Post-test) was higher than T1 (pre-test).

Based the data that showed above, it can be concluded that using relia as media was considered to improve tenth grades students' ability in writing descriptive text.

\section{BIBLIOGRAPHY}

Cohen A.D. (1996). Assessing Language Ability in the classroom (2nd Edition). Boston USA: Heine and Heinle publisher.

Liando, N. (2012). Bilingual and Regular Class Students' Attitutes Towards English. Litera, Vol.11, Number 2.

Maru, M. G., \& Liando, N. V. (2016). The Application of Jeremiad Approach (TEx Approach) on Essay Writing: Listening to Students' Voice. The 63rd TEFLIN International Conference: Universitas PGRI Adi Buana Surabaya.

Maru, M. G. (2009). Engaging Literary Text to Language Exposures for Foreign English Learners. International Conference on TEFL/COTEFL in Muhammadiyah University.

Moore, G. W. (1983). Developing and Evaluating Educational Research. Boston: Little, Brown and Company.

Rusman. (2005). Model-Model Pembelajaran Mengembangkan Profesionalisme Guru. Jakarta: PT Raja Grafindo Persada. 